Jens Kaalhauge Nielsen

\title{
Kriterierne for Gronlands økonomiske bæredygtighed - og deres strategiske implikationer
}

\begin{abstract}
Onsket om en baredygtig udvikling har lienge varet en generel malsatning for det gronlandske politiske liv, men det gronlandske samfund er langt fra at have realiseret en sădan malsatning. Artiklen tager udgangspunkt i to begreber om baredygtighed: Okonomisk baredygtighed og societal baredygtighed. Den herskende debat om Gronland har haft tendens til at anskue Gronlands erhvervsmassige problemer som afstedkommet af den historiske institutionalisering af samfundets allokative mekanismer. idet tyngden i debatten har kredset om en kritik af det offentliges rolle og er blevet artikuleret som et slogan om "liberalisering" og "privatisering" af markedskrafterne. Denne position har năet sit hojdepunkt $\mathrm{i}$ den seneste OECD-rapport. Artiklen tager udgangspunkt $\mathrm{i}$ den opfattelse, at de egentlige erhvervsmassige problemer ikke skal soges $\mathrm{i}$ institutionaliseringen af den allokative orden, men snarere må findes i produktionsaspektet af den societale struktur.
\end{abstract}

Det nuvarende problem:

\section{Bæredygtighed}

Den 1. maj 1999 fejrede Grønlands Hjemmestyre sit 20 års jubilæum, og dette giver os lejlighed til at vurdere, hvor langt det grønlandske samfund er kommet $\mathrm{i}$ dets bestræbelser på at realisere en baredygtig udvikling. For der er ingen tvivl om, at der er meget at fejre, når Hjemmestyrets resultater skal gores op. Grønland er et stabilt og professionelt styret samfund med en særdeles veludviklet, højteknologisk infrastruktur, samt en økonomi præget af en stram finanspolitik med en bemærkelsesværdig lav inflationsrate. Jo, der er så mange tegn på både stabilitet og udvikling $\mathrm{i}$ samfundet, at næsten enhver kan finde noget at glæde sig over.

Pă samme tid mă vi ogsá notere os, at det oprindelige mål for de gronlandske politikere ved hjemmestyrets start, "at stá pá egne ben" ved selv at overtage de grundlæggende sagsområder i den danske stats forvaltning af Gronland, er en drøm, der stort set er blevet realiseret, idet selv råstofdirektoratet $\mathrm{er}$ blevet overflyttet. Selv rigsfællesskabets urørlige instans, udenrigspolitikken, er i stigende grad blevet genstand for aktiv grønlandsk deltagelse. På denne vis viser Gronland alle tænkelige tegn på at være en selvstyrende enhed, men er det også en bæredygtig enhed? Det er et ganske andet spørgsmål.

Inden vi bliver for begejstrede for Hjemmestyrets positive resultater, må vi nodvendigvis vende opmærksomheden mod systemets akilleshæl. Grønland er et samfund, der ikke er bæredygtigt $i$ økonomisk forstand og på afgørende vis heller ikke i societal forstand. 'Gronlandsk okonomi er afhængig af store bloktilskud og andre typer af ydelser, som repræsenterer $60 \mathrm{pct}$. af de samlede offentlige udgifter (Gronlands Statistik, 1998: 442). Samtidig er Grønland særdeles afhængig af tilstedeværelsen af danske professionelle eksperter. Men spørgsmålet om den societale bæredyg- 
Jens Kaalhauge Nielsen

\title{
Kriterierne for Gronlands økonomiske bæredygtighed - og deres strategiske implikationer
}

\begin{abstract}
Onsket om en baredygtig udvikling har lienge varet en generel malsatning for det gronlandske politiske liv, men det gronlandske samfund er langt fra at have realiseret en sădan malsatning. Artiklen tager udgangspunkt i to begreber om baredygtighed: Okonomisk baredygtighed og societal baredygtighed. Den herskende debat om Gronland har haft tendens til at anskue Gronlands erhvervsmassige problemer som afstedkommet af den historiske institutionalisering af samfundets allokative mekanismer. idet tyngden i debatten har kredset om en kritik af det offentliges rolle og er blevet artikuleret som et slogan om "liberalisering" og "privatisering" af markedskrafterne. Denne position har năet sit hojdepunkt $\mathrm{i}$ den seneste OECD-rapport. Artiklen tager udgangspunkt $\mathrm{i}$ den opfattelse, at de egentlige erhvervsmassige problemer ikke skal soges $\mathrm{i}$ institutionaliseringen af den allokative orden, men snarere må findes i produktionsaspektet af den societale struktur.
\end{abstract}

Det nuvarende problem:

\section{Bæredygtighed}

Den 1. maj 1999 fejrede Grønlands Hjemmestyre sit 20 års jubilæum, og dette giver os lejlighed til at vurdere, hvor langt det grønlandske samfund er kommet $\mathrm{i}$ dets bestræbelser på at realisere en baredygtig udvikling. For der er ingen tvivl om, at der er meget at fejre, når Hjemmestyrets resultater skal gores op. Grønland er et stabilt og professionelt styret samfund med en særdeles veludviklet, højteknologisk infrastruktur, samt en økonomi præget af en stram finanspolitik med en bemærkelsesværdig lav inflationsrate. Jo, der er så mange tegn på både stabilitet og udvikling $\mathrm{i}$ samfundet, at næsten enhver kan finde noget at glæde sig over.

Pă samme tid mă vi ogsá notere os, at det oprindelige mål for de gronlandske politikere ved hjemmestyrets start, "at stá pá egne ben" ved selv at overtage de grundlæggende sagsområder i den danske stats forvaltning af Gronland, er en drøm, der stort set er blevet realiseret, idet selv råstofdirektoratet $\mathrm{er}$ blevet overflyttet. Selv rigsfællesskabets urørlige instans, udenrigspolitikken, er i stigende grad blevet genstand for aktiv grønlandsk deltagelse. På denne vis viser Gronland alle tænkelige tegn på at være en selvstyrende enhed, men er det også en bæredygtig enhed? Det er et ganske andet spørgsmål.

Inden vi bliver for begejstrede for Hjemmestyrets positive resultater, må vi nodvendigvis vende opmærksomheden mod systemets akilleshæl. Grønland er et samfund, der ikke er bæredygtigt $i$ økonomisk forstand og på afgørende vis heller ikke i societal forstand. 'Gronlandsk okonomi er afhængig af store bloktilskud og andre typer af ydelser, som repræsenterer $60 \mathrm{pct}$. af de samlede offentlige udgifter (Gronlands Statistik, 1998: 442). Samtidig er Grønland særdeles afhængig af tilstedeværelsen af danske professionelle eksperter. Men spørgsmålet om den societale bæredyg- 
tighed går langt videre end dette. Det handler dybest set om, hvorvidt det gronlandske samfund har tilstrækkelige sociale og menneskelige ressourcer til at indfri den funktionelle rollekompleksitet, som et moderne samfund hviler pá. Kun i den udstrækning det gronlandske samfund i fremtiden kan udfylde alle de relevante strategiske akser i denne kompleksitet, på en måde der er tilstrækkeligt socialt meningfuld, kan man i dybeste forstand sige, at den er bæredygtig. Det er $\mathrm{i}$ hvert fald klart, at Gronland i dag ikke i tilstrækkelig grad er i stand til at indfri denne forudsætning. For selvom sporgsmålet om bxredygtighed ofte diskuteres som et rent økonomisk element, sã er kernen i problematikken pa ingen måde reducerbar til okonomiens genstandsfelt. De økonomiske spørgsmål er blot toppen af isbjerget.

\section{Den udviklingsmæssige faktor}

Der er to fundamentale faktorer, der definerer præmisserne for Grønlands nuværende situation. Den ene er historiskudviklingsmæssig og den anden er af socio-demografisk karakter.

Hvad angår det forste punkt begyndte Gronland sin moderniseringsproces relativt sent, nemlig $\mathrm{i}$ årene efter den anden verdenskrig, hvor G-50 planen blev iværksat. Derfor har samfundet kun haft et halvt hundrede år til at tilpasse sig den moderne verdens komplekse rationalitet og differentieringsgrad. Det er klart, at en "latecomer" til den globale udvikling vil være eksponent for relativ "historisk forsinkelse". Det virkelige problem, når det drejer sig om udviklingsmassig forsinkelse, er ikke tilegnelsen af rent tekniske færdigheder, eller rollestrukturens rent sociale komponent. Kulturelle systemer og deres socialisations-psykologiske mekanismer er langt mere "kon- servative" og "træge" instanser, som i deres grundkerne forandrer sig langsomt over tid.

Det gronlandske samfunds evne til at gennemfore denne proces har varet dobbelttydig og asymmetrisk. Pả den ene side har man på succesfuld vis tilpasset sig store sociale og teknologiske ændringer, samtidig med at man på den kulturelle side har skabt en vis integral symbiose mellem gronlandske og danske elementer. Ikke desto mindre er der en del af udviklingen, som aldrig rigtig er kommet godt fra start. Man har tilladt industristrukturen at blive fastfrosset i et traditionelt mønster, som grundlæggende set er blevet fikseret omkring en endimensional faktor, nemlig fiskeri. Samtidig har denne fiksering betydet, at visse sociale konflikter og patologier er blevet fastlåst $\mathrm{i}$ et art lukket rum.

\section{Mikrostatens problemer}

Den anden grundlæggende komponent for Gronlands nuværende situation har jeg kaldt socio-demografisk, og med det mener jeg det forhold, at Grønland er en af denne verdens mindste mikrostater, og således underlagt det universelle mønster af imperativer, der er gyldige for mikrostater.? En af årsagerne til Grønlands strukturelle erhvervsproblemer ligger netop i det særlige sæt af dilemmaer, der præger mikrostaten som aktør.

Et af de mest grundlaggende trak ved en mikrostat er, at dets hjemmemarked er meget lille og dets importkvote særdeles stor. Det betyder, at en mikrostats industristruktur må være eksportorienteret i tilsvarende grad for at ligevægt på handelsebalancen kan opretholdes. Pâ den anden side er en mikrostats befolkningsbase i reglen sâ lille, at det er meget svært at tilfredsstille hele det plu- 
rale spektrum af et moderne samfunds variationsformer. Det betyder. at der er granser for. $\mathrm{i}$ hvilken grad og med hvilken intensitet en mikrostat kan tilfredsstille de nodvendige niveauer af societal og okonomisk differentiering af sin sociale struktur. Mikrostater har isar problemer med at rade over det nodvendige antal specialister til hele spektret af relevante samfundsmassige funktioner. Endvidere har mikrostater problemer med at opna den "kritiske masse" i graden af institutionalisering af samfundets systemiske funktioner, hvilket inden for okonomien blandt andet handler om at kunne opnå fordelene ved stordrift.

Når vi studerer effekterne af Gronlands historiske forsinkelse, må vi rent analytisk skelne imellem den type problemer, der er knyttet til Grønlands status som mikrostat og den type problemer, der har idiosynkratisk karakter, dvs. er effekter af den sxrlige historiske udvikling, hvorunder de gronlandske samfund og institutioner har fundet deres form og særlige kulturelle livsverden. De rent civilisatoriske aspekter ${ }^{3} \mathrm{i}$ den historiske forsinkelse kan som regel indhentes med tiden, men mikrostatens formlogiske problemer er universaltstrukturelle, og fremstår således som permanente udfordringer.

\section{Gronlands særlige status som mikrostat}

Det er væsentligt at notere sig, at Grønland er en ret enestående mikrostat (jf. Kaalhauge Nielsen, 1999b). Det, der kendetegner de fleste mikrostater, er ikke blot, at de har et meget lille befolkningsgrundlag, men også at de som regel har til huse inden for et lige så lille landområde. Dvs. de fleste mikrostater er stækket både demografisk og geografisk. Pâ dette punkt har Gronland helt klart en særstilling. for selvom det er en af de allermindste mikrostater, så er den placeret pá verdens storste o med et areal. der er seks gange storre end Japan og selv fratrukket indlandsisen pa omtrentlig storrelse med Usbekistan. Det er ikke for meget sagt, at Gronland billedligt set er som en myre, der rider på en gigantisk kolos. Med andre ord, Gronland har et geografisk potentiale, som ingen anden mikrostat, bortset fra Nunavut, er i besiddelse af. Det betyder, at Gronland i det lange lob formentlig vil vare i stand til at få store okonomiske indtægter, både fra råmaterialer og turisme. Det faktum, at disse to sektorer for øjeblikket er helt eller delvist økonomisk døde, ændrer ikke på dette forhold.

Gronlands muligheder for at blive bæredygtig er således sammenlignet med mange andre mikrostater særdeles positive, når de langsigtede geopolitiske potentialer skal vurderes. Men de positive geopolitiske potentialer står ikke mål med de nuværende realiteter, for mens mange andre mikrostater $i$ verden med rimelig succes er begyndt at vriste sig ud af endimensionalitetens fælde og at differentiere deres erhvervsliv, ${ }^{+}$har Gronland sovet trygt under bloktilskuddenes søvndyssende tæppe, mens den faktiske okonomi er stagneret og de faktiske udviklingsmuligheder forspildt.

Hvis den nuværende udvikling fortsatter, vil Gronland uvægerligt sakke bagud $\mathrm{i}$ både industrikapacitet og levestandard, selvom bloktilskuddet for en tid endnu vil kamuflere tingenes faktiske tilstand.

Det afgorende er, at Gronland selv kommer ud af sin nærmest søvngængeragtige satsning pá en endimensional industristruktur og kommer $i$ gang med at reorganisere sine societale kapaciteter $\mathrm{i}$ en anden retning. Dette er lettere sagt end gjort, men det afgorende er, at pro- 
cessen kommer i gang, og at den får forsteprioritet inden for det politiske beslutningssystem. For politisk set vil det blive nodvendigt at træffe en række meget afgørende valg, hvad angår morgendagens grønlandske industristruktur. I sin egenskab af mikrostat kan Gronland ikke vandre ad tusinde veje på en gang; tvartimod må der fra politisk side blive sat nogle klare prioriteter.

Lad mig kort opremse nogle elementer i en sådan strategi. For det forste må Gronland fremfor alt - målbevidst og uden forsinkelse - iværksætte en differentiering af sin erhvervsstruktur. Denne proces má koordineres med en satsning på elementer $\mathrm{i}$ de højere uddannelser, der er i overensstemmelse med de specialiseringsbehov, der ligger implicit i den valgte differentieringsstrategi. Den nye industristruktur skal være organiseret omkring en åben og eksportorienteret økonomi, og tyngden af den nye struktur skal være rettet mod en meget lille klynge af prioriterede erhvervssektorer. Samtidig må informationsteknologiens muligheder tilpasses på følsom vis til lokale forhold, således at en utopisk overtro på IT-fænomenet undgås. Det er vigtigt, at Grønland inden for hver sektor er i stand til at fremvise et minimum af organisationsmæssig tyngde. Det må også sørge for, at hver sektor har det nødvendige samfundsmæssige støttesystem, herunder de nødvendige finansielle investeringsmidler. I et samfund som Grønland er der historiske betingelser, der fortæller os, at sådan et støttesystem ikke kan etableres på realistisk vis uden en stærk offentlig sektor. Det betyder, at hjemmestyrets stærke, centrale rolle i det grønlandske samfundsliv på ingen måde kan ses som et udtryk for en forældet struktur eller en eller anden type social patologi. Der er afgørende grunde til, at en lille mikrostat som Grønland med et historisk "uudviklet" civilt samfund nodvendigvis ma bibeholde en relativt stor offentlig sektor for at skabe tilstrækkelig gennemslagskraft $\mathrm{i}$ landets muligheder som international aktør.

\section{Den voksende kritik af den offentlige sektors rolle i Gronlands okonomi}

Hjemmestyrets størrelse og rolle i økonomien er ikke blot blevet sat til debat, men bliver også i stigende grad udsat for særdeles intensiv kritik. En af de mest markante kritikere af hjemmestyret er Martin Paldam (1994), der har fremført en intelligent $\mathrm{og}$ systematisk kritik. Ifølge Paldam er hjemmestyret administrativt overopsvulmet, et mærkværdigt kunstprodukt holdt $\mathrm{i}$ live af den danske stat og i økonomisk forstand særdeles ineffektiv $i$ sin administration af samfundet. Med dets overgenerøse serviceydelser og ideforladte understøttelsesmentalitet resulterer dets politik i langt mere ondt end godt. Hjemmestyrets økonomi resulterer ikke blot i kvælning af spirerne til privat foretagsomhed, men skaber - kombineret med det høje grønlandske omkostningsniveau - en art latent, strukturel inflation, den såkaldte hollandske syge. Paldam er endda gået så langt som til at sammenligne Grønland med Nordkorea. I Sulisapublikationen Mål og strategier i den gronlandske erhvervsudvikling fra 1998 produceret af et forfatterteam (Danielsen et al., 1998) finder vi en i princippet tilsvarende kritik af den offentlige sektors uhensigtsmæssige magt, om end kritikken modsat Paldams fremfores på en indirekte og underspillet vis og pá det nærmeste skal læses mellem linierne. Ikke desto mindre falder Sulisa-holdets konklusioner på linie med Paldams, hvad angår fremhævelsen af en afgorende skævhed i forholdet mellem offentlige 
og private institutioner i Gronlands okonomi. Pa samme vis lagde det râdgivende udvalg vedrorende Gronlands okonomi under ledelse af professor Christian Sorensen i dets rapport fra 1998 (Det radgivende udvalg vedrorende Gronlands okonomi. 1998) stort set op til den samme grundtematisering som Paldam og Sulisa-holdet. Ogsà her var den grundlaggende anbefaling en liberalisering af okonomien.

Det er inden for denne voksende kritik af det offentliges rolle $i$ den gronlandske okonomi, at vi skal anskue den seneste OECD-rapport, som på mange måder representerer en endnu mere renlivet pro-markedsorientering, end den der på forskellig vis blev fremfort af Paldam, Sulisa- og Sorensen-holdet. Det er ikke for meget sagt, at OECDrapporten er ultraliberalistisk i sin approach, og i en vis forstand repræsenterer den logiske konsekvens af den retning, som den toneangivende del af den gronlandske debat om okonomi og erhvervspolitik $\mathrm{i}$ de senere år har taget.

\section{OECD-rapportens ideer og påstande}

OECD-rapporten (Thomasen et al., 1999) prasenterer sin analyse som en generel strategi for det gronlandske samfund. Det er rapportens formâl at foreskrive veje til at skabe en mere dynamisk okonomisk udvikling i Gronland. OECD-teamet hæfter sig ved. at den gronlandske okonomi $\mathrm{i}$ de sidste 10 ăr har varet præget af stagnation, og konkluderer, at stagnationen er tegn pá, at der mangler tilstrækkeligt dynamiske incitamenter i okonomien. En grundlaggende præmis i rapporten er pastanden om, at der i Gronland skulle findes et stort "uudnyttet potentiale for private og lokale initiativer i alle sektorer af erhvervslivet", $o g$ at det grundlæggende sporgsmal simpelthen er at fa frigjort disse store private og lokale potentialer. Ifolge rapporten star tallose private gronlandske ivarksettere săledes på spring og venter pa det store ojeblik. når markedet kan bliver liberaliseret. Logikken i rapporten er. at nar blot markedet bliver befriet. er en ny industristruktur pá det narmeste allerede pá vej. Selvfolgelig skal denne proces ifolge rapporten folges op med aktiviteter angående uddannelse og iværksætterkultur. men for OECD-okonomerne er disse faktorer sekundære sammenlignet med sporgsmålet om markedets befrielse, der er selve analysens magiske punkt.

OECD-rapporten remser op, hvad der skal til for at frigore markedskræfterne i Gronland. Enprissystemet må sættes ud af kraft i de forende vækstbyer, og fremfor ait mâ den offentlige sektors rolle i okonomien reduceres starkt, ligesom de offentlige selskaber i videst muligt omfang må privatiseres. I tilgift hertil skal det private marked ábnes for udenlandsk kapital og investorer, som også må have mulighed for at erhverve sig de privatiserede offentlige virksomheder. Fortrinsret for folk, der er født i Gronland, eller har serlige relationer til Gronland, hvad angâr investeringer, skal afskaffes. Dertil kommer, at alle konkurrenceforvridende skavheder i markedet skal udjævnes, monopoler skal ophæves, ligesom krav om næringsbrev skal fjernes, ensfragtafgiften skal afskaffes, og boligmarkedet skal dereguleres. De grundlæggende kodeord i disse foranstaltninger er at frigere og skabe gennemsigtighed pá markedet.

Selvom rapporten lidt rapsodisk taler om iværksætterkultur og uddannelse. sả er rapportens centrale tema den store vision om liberalisering af det okonomiske marked. OECD-teamets grundlæggende credo er sâledes formuleret $\mathrm{i}$ 
folgende passus: "I en markedsokonomi sikrer prissystemet, at ressourcerne bruges på en effektiv måde. Der eksisterer ikke en sådan mekanisme i forbindelse med udbud af offentlige goder og tjenesteydelser" (Thomasen et al., 1999: 10; se også p. 55).

Det er på disse aksiomatiske præmisser, hele logikken i OECD-teamets argumentation hviler, og hele deres projekt stăr og falder med sandhedsværdien af dette udsagn. Det interessante er dog, at der er to afgorende steder i rapporten, hvor OECD-økonomerne kommer ind på potentielt fatale begrænsninger $\mathrm{i}$ deres egen argumentation. Det ene sted siger de: "På grund af de meget små markeder i Gronland er der imidlertid nogle naturlige monopoler, som er og vil være uundgå̉elige" (Thomasen et al., 1999: 11). Dernæst anfører de også: "Med en lille befolkning spredț over et enormt område er det ikke muligt at komme bare i nærheden af en perfekt konkurrencesituation i Gronland" (Thomasen et al., 1999: 12).

\section{En kritik af OECD-rapportens aksiomatiske forudsætninger}

I det følgende vil jeg kritisere det metodiske og aksiomatiske grundlag for OECD-rapporten (jf. også Kaalhauge Nielsen, 1999c), idet jeg vil minde om, at der ikke inden for samfundsvidenskaben og heller ikke inden for økonomien som disciplin eksisterer nogen endegyldig konsensus om, hvorledes man skal forstå forholdet mellem "marked" og "samfund" som to kategoriale instanser. Ikke desto mindre kan vi konstatere, at OECD-rapporten fremstår som eksponent for en meget bastant fortolkning af dette forhold, idet markedet i dets rene form fremstilles som den ypperste allokative mekanisme i samfundet. Marke- det præsenteres af forfatterne som indehaveren af en velsignelsesfuld effektivitet, som er alle andre societale allokeringsmekanismer overlegne, ikke mindst hvad angår dem, som befinder sig i det "offentlige" felt.

Det er denne ide, der ligger til grund for rapportens mekanistiske analysemåde. For dybest set har OECD-holdet kun ét svar og én løsning til alle spørgsmål: Lad de frie markedskræfter rảde $o g$ alt vil blive godt.

Analytisk set er OECD-rapporten et typisk eksempel pâ det, man kalder økonomisme. Dette forhold ligger allerede implicit i rapportens mission, siden det stiltiende tages for givet, at en ren økonomisk analyse kan frembyde grundlaget for en strategi for Gronland. Men i rapportens økonomisme ligger både dens entusiastiske budskab og dens immanente svaghed. For rapporten kan ikke inden for sit eget utilitaristiske skema give nogen tilfredsstillende forklaring på sociale fænomener. Så i teoretisk-metodisk forstand må rapporten konstant forlade det rent okonomiske genstandsfelt $o g$ gå på strandhugst $i$ residualerne, det vil sige i det ikke-økonomiske felt, fordi det bliver indlysende, at analysemåden har forfærdelig lidt at sige om andet end markedsabstraktionen, der i dybeste forstand er substantielt tom. På denne vis bliver rapporten tvunget til at tage emner op som uddannelse, iværksætterkultur, human kapital, sociale normer og andre sociokulturelle størrelser. Men de ting, som rapporten kan sige om disse ting, bliver bemærkelsesværdigt stakåndede og páklistrede, for rapporten er ikke i besiddelse af nogen teori, som kan give dens overvejelser dybere relevans eller mening. I sin diskussion af iværksætterkulturen erkender rapporten godt nok, at "en sund makroøkonomisk udvikling ikke i sig 
selv er tilstrakkelig til at udvikle ivarksatterkulturen" (Thomasen et al.. 1999: 76). Men alt, hvad rapporten kan tilbyde. hvad angår udviklingen af en ivarksætterkultur, er netop blot og bart elementer af et makrookonomisk rasonnement. Rapporten peger pà, at en ivarksatterkultur vokser ud af "kulturelle holdninger", men har intet bud pa dette begreb eller på transformationslogikken mellem kulturelle holdninger og ivarksatterkultur, som i OECD-rapporten fremstår som et rent mysterium. I mangel af bedre snakker rapporten los om, at "rammebetingelserne skal være tilstede", men det virker tomt og hult, siden rapporten klart demonstrerer, at den ikke har skyggen af teoretisk ide om, hvad "det" er, som de såkaldte rammebetingelser egentlig skal vare ramme om.

På denne vis er hele OECD-rapportens argumentation organiseret rundt om et lukket system, der bygger på en tautologisk opfattelse af kriterierne for produktionsfaktorernes allokative effektivitet. Samfundsmæssig effektivitet er opfattet som noget, der er måleligt og "gennemsigtigt" inden for et pluralt aktørunivers, hvor individuelle aktører konkurrerer om de højeste grader af effektivitetskvanter, og hvor vækst måles i pengemediets form. Det er en stiltiende, aksiomatisk forudsatning i OECDrapporten, at de ultimative mål $\mathrm{i}$ markedsinstitutionen mâ være samstemmende med de ultimative mål $\mathrm{i}$ den samfundsmæssige produktionsproces. Når rapporten hævder at opstille en økonomisk strategi, să siger den implicit. at dette ogsá bør være en strategi for samfundet. Hvad den glemmer, er spørgsmålet om, hvorvidt en dybere forståelse af dynamikken i de strukturelle samfundsmæssige produktionsfaktorer, herunder sporgsmålet om "effektivitet", overhovedet kan vare meningsfyldt organiseret omkring en afregning af pengemediets semiotik? Vi bor i den sammenhang genkalde os Ludwig von Mises's ord: "The attempts to determine in money the wealth of a nation or the whole of mankind are as childish as the mystic efforts to solve the riddles of the universe by worrying about the dimensions of the pyramid of Cheops" (Mises, 1966: 217).

Centralt $i$ rapporten finder vi en analytisk besattelse med Gronlands distributive problemer. Denne besattelse fokuserer på det institutionelle design af allokeringsmekanismerne i Gronland, idet rapporten er totalt besat af sporgsmålet om, hvorvidt denne allokering kan siges at foregå $\mathrm{i}$ "privat" eller "offentligt" regi. Det interessante i rapporten er det stærkt dikotomiserede billede, der bliver dannet af fanomenerne "privat" versus "offentlig". På denne måde skabes en forestilling om, at det "private" versus det "offentlige" står $\mathrm{i}$ et forhold til hinanden, som tese står til antitese i vulgær dialektik. I henhold til denne logik er det evident, at hvis det offentlige har noget, så må det private mangle det. Og så fremdeles. Så hvis det er "godt" for den private sfære at vare $i$ besiddelse af "A", er det "forkert" for den offentlige at være i besiddelse af det samme. På denne vis er OECD-økonomerne febrilsk interesserede i hvem, der har okonomisk magt, og hvem der har nytte af den økonomiske magt, idet magten ifølge disse analytikere jo enten må være det ene eller det andet sted. For det er en implicit ide, der gennemsyrer OECD-okonomernes analyse af magt, at magt er noget "som en eller anden besidder" eller "har". For hvad skulle det dog ellers være?

Latent i OECD-rapporten ligger den ide, at samfundets politiske funktioner 
kan blive radikalt adskilt fra det okonomiske system. Det tages for givet, at en stærk adskillelse af samfundets politiske og okonomiske sfærer per definition er noget "godt". Man fornemmer en nærmest religiøs iver $\mathrm{i}$ den måde, hvorpå OECD-holdet søger at gennemtvinge en adskillelse af politik og okonomi. For dem bliver det et helligt princip, at okonomien, dvs. det frie marked, skal være ubesmittet af det politiske liv. Aksiomet er således, at kun gennem en uforstyrret okonomisk sfare kan den samfundsmæssige rigdom blive allokeret optimalt. Rapporten bygger således på en håbløs simplistisk forestilling om, at den moderne differentieringsproces af det sociale systems institutionaliserede matrix er en simpel linear proces, hvor "subsystemer" simpelthen udskilles i renere og renere form. De fatter ikke, at det moderne samfunds differentieringsprocesser er komplekse, dobbeltvirkende ordningsformer, som i praksis består af en symbiotisk udveksling mellem differentiering og den type integrale processer, som vi med en sociologisk term kalder "interpenetration" (se Münch, 1990).

I al deres ihærdighed glemmer OECD-økonomerne at stille et ganske væsentligt spørgsmål, nemlig: hvad er de egentlige betingelser for rigdom? For rigdom er en generaliseret kategori, som ikke blot skal fordeles, men ogsă produceres. OECD-okonomerne har så travlt med, hvorledes rigdom allokeres, at de helt glemmer at spørge, hvorledes den er produceret.

Problemet er, at rapporten ikke har noget bud på "produktionsaspektet" af den grønlandske økonomiske virkelighed. Det er karakteristisk, at bortset fra de konstante appeller til markedsmetafysik præsenterer OECD-rapporten ikke nogen vision for den grønlandske indu- strielle strukturs fremtid. Rapporten tilbyder ingen serios diskussion af, hvorledes den industrielle struktur skal differentieres, og under hvilke betingelser en sådan differentiering skal være mulig.

Det værste ved rapportens fiksering på okonomiens allokative problemer er netop, at den trækker opmærksomheden bort fra den grønlandske okonomis egentlige problemer, som er af dybereliggende strukturel karakter. Disse problemer handler om de grundlaggende skæwheder i Gronlands okonomiske design, og resulterer $i$ et krav om differentiering af den industrielle struktur, ligesom det indbefatter sporgsmålet om den politiske prioritering af societale kapaciteter. Reorganisering af Gronlands industrielle struktur handler derfor heller ikke om et abstrakt krav om "privatisering", men om hvorledes Gronland mobiliserer sine kollektive ressourcer og udvikler nye verdensmarkedsorienterede industrier, der er så avancerede, at de kan gøre sig håb om at fastholde Grønlands nuværende levestandard.

I deres mekaniske bestræbelse på at bevise deres models universelle gyldighed glemmer OECD-økonomerne at tage Grønlands specielle historiske og geografiske situation i ed. For hvad nu hvis Gronlands historiske og geografiske betingelser er afgørende for den grønlandske okonomi? Og hvad nu hvis OECD's abstrakte model ikke passer til det grønlandske tilfælde?

OECD-rapportens mangel på historisk fornemmelse bliver meget klar, nár man iagttager den måde, hvorpå den anvender sammenlignede statistik. For når rapporten klager højlydt over det forhold, at Gronlands Statistik ikke kan levere de data, som OECD-rapporter "normalt" benytter sig af (Thomasen et al., 1999: 30), så afslører OECD-teamet dermed også deres aksiomatiske ide om, 
at Gronland blot er et nummer i rakken af den normale standardoperation. der prager OECD-rapporter. Gronland skal passe ind idet "normale" analysemaskineri. ellers er der noget galt. For man kunne forestille sig. at det ville vare relevant, at Gronland som arktisk land primert skulle blive sammenlignet med andre arktiske og subarktiske omrâder. som deler afgorende lighedspunkter i historiske og geografiske betingelser. Man kunne forestille sig, at det ville vaere naturligt at sammenligne Gronland med Nunavut, Northwest territoriet, Yukon, Alaska, Labrador, Murmansk Oblasken og Finnmarken og Tromsområdet i Norge. Men nej, da dette falder uden for OECD's normale sammenligningsfelt, kan en sådan sammenligning ikke anvendes, og derfor finder OECD det langt mere relevant at sammenligne Gronland med Korea, Japan, Grækenland, Mexico, New Zealand, Ungarn og Tjekkiet. $\mathrm{Og}$ når $\mathrm{OECD}$-rapporten gor det, finder den ud af, at Gronland har et usædvanligt højt omkostningsniveau vis-a-vis bruttonationalproduktet per capita. Hvis den havde sammenlignet Gronland med andre arktiske lande, så ville konklusionen om Gronlands omkostningsniveau bestemt have varet en anden. Det samme synes at være tilfældet på en lang række andre indikatorer, blandt andet antallet af offentligt ansatte. Når OECD-rapporten omtaler Gronland som et "ekstremt tilfælde", må man sporge, i kraft af hvilket sammenligningsgrundlag?

Uden at fremsta som en ensidig eksponent for det offentlige som "sakralt princip", er det vigtigt at forholde sig kritisk til den made, hvorigennem OECDrapporten soger at diskreditere det offentlige som okonomisk aktor. For har vi ikke OECD-okonomernes ord for. at det gronlandske marked aldrig vil blive per- fekt, ja. som de selv udtrykker det "ikke blot tilnermelsesvis perfekt". Hvis det er tilfaldet, sả er det selv ud fra OECD: egen logik svaert at se, hvorfor det skulle vere illegitimt, at det offentlige er et integralt element i markedsforholdene. Det afgorende er dog, at $i$ analysen af de sarlige betingelser, der galder for Gronland, holder OECD's teoretiske fundament overhovedet ikke. uanset hvordan man vender og drejer det.

Det afgorende er, at der er meget stærke historiske grunde til, at det gronlandske samfund ikke har råd til at overlade de okonomiske processer til det såkaldte frie marked eller afgorende forstyrre den institutionelle balance, som landet mojsommeligt har opbygget. For der er dybest set ikke meget frit marked og ikke tilstrakkelig privat foretagsomhed i Gronland. Derfor må man acceptere, at det offentliges rolle i Gronland er anderledes end $\mathrm{i}$ andre lande, også hvad angår det økonomiske område.

Det er dog vigtigt at forstå, at mit indlæg ikke må opfattes som en kategorisk afvisning af privatisering som et muligt element i Gronlands langsigtede udvikling. Mit argument handler derimod om, at sporgsmålet om privatisering ikke må overskygge det langt vasentligere sporgs-mål om industriel differentiering. Med mindre vi făr en differentieret okonomi, bliver der ikke meget at privatisere. Det er måske at gå for langt at havde, at den nuværende privatisering i Gronland er et fatamorgana under bloktilskuddenes regi, men det er sikkert sandt at sige, at bloktilskuddenes tilstedevarelse indbyder til et falsk billede af de objektive muligheder for privatisering under de nuværende omstandigheder. Privatiserings-debatten kommer i vejen for en dybere forståelse af Gronlands erhvervsstrukturelle problemer og nodvendigheder. 


\section{Konklusion}

Problemet med OECD-rapporten er, at den er ude af stand til at fokusere pa de virkelige sporgsmål $\mathrm{i}$ den gronlandske okonomi. Disse sporgsmål er grundet $\mathrm{i}$ Gronlands sarlige situation og dets historie. Problemet med rapporten er, at den på nærmest mekanisk vis fokuserer på magtorganisatoriske spørgsmål inden for den allokative sfære ud fra en ekstremt utilitaristisk fortolkning af markedets potentialer, frem for at tilbyde en systematisk analyse af de grundlæggende problemer i Gronlands okonomi, der handler om produktionsmådens strukturelle form.

Det virkelige problem med OECDrapporten er således, at den leder fokus bort fra de egentlige problemer i Grønland, nemlig spørgsmálet om, hvorledes Gronland fẳ startet en proces, der kan lede frem mod en differentiering af Grønlands industristruktur. Uden løsningen på dette spørgsmål bliver al snak om allokeringsspørgmålet et slag i luften, der alligevel ikke rigtig gor nogen forskel.

Det virkelige sporgsmål i Grønland handler således ikke om for enhver pris at nedbryde monopoler, men at sikre den nødvendige organisatoriske tyngde i designet af Gronlands erhverv. Gronland har ingen interesse $\mathrm{i}$ atomisering og fragmentering af sine erhverv. Det virkelige sporgsmâl i Grønland handler heller ikke om relative grader af "frihed" i et marked, der dybest set ikke eksisterer. Det virkelige sporgsmål handler om, hvorledes Grønland făr bevæget sig ud over en endimensional erhvervsstruktur, der ikke længere er i stand til at tilbyde tilstrækkelig beskæftigelse, og satser pá helt nye og udfordrende eksportorienterede industrier, som modsvarer de krav og udfordringer, der hører til $i$ en højteknologiseret og informationssensitiv verden. En sadan proces vil ikke blive let, men er bydende nødvendig.

Gronland er en mikrostat med usædvanlige muligheder for på lang sigt at nå frem til en selvbærende okonomi, ikke blot i okonomisk forstand, men formentlig også qua et societalt kriterium." Dette vil ikke kunne ske, medmindre en industriel differentiering bliver sat i værk. I dette ligger noglen til al fremtidig succes. Grundlaget for denne proces er dog, at Gronland tager et tigerspring inden for det uddannelsesmassige felt, for ellers vil landet ikke i tilstrækkelig grad have evnen til at koble sig ind $i$ de "windows of opportunities", som viser sig inden for verdensmarkedets udviklingslogik, og som bliver afgørende for morgendagens sociale hierarkisering af verden.

I Grønland må opmærksomheden være koncentreret om en systematisk opdyrkning af de societale kapaciteter, som peger frem mod en ny IT-sensitiv erhvervsstruktur. Samtidig er det dog vigtig at minde om et potentielt dilemma: Ultimativt set er et samfunds societale kapaciteter ikke blot et stykke legetøj for dets makroøkonomiske drømme, men forst og fremmest en funktion af dets kulturelle værdier. Derfor er spørgsmålet om deres form og udviklingsretning et metapolitisk spørgsmål, eller det som Oswald Spengler kalder "high politics". Problemet er, at năr man vælger en industriel struktur, så vælger man ikke blot en ren okonomisk mekanisme til finansiel succes. Man vælger også i en tilstrækkeligt afgørende grad de kulturelle værdier, der skal være "operative", dvs. normativt gyldige for samfundet. Men et sådan valg er andet og mere end blot et valg af erhvervspolitik - det er i afgorende grad valg af ens egen kulturelle skæbne. 


\section{Noter}

1. Okonomisk baredygtighed handler om. horvidt okonomien som produktionssystem er selshjulpen malt med relevante kriterier for okonomisk ydeerne. Societal beredygtighed handler om, hrorvidt det societale fellesskab er i besiddelse af de tilstrackikelige societale kapaciteter til at udfylde det rolleregister, som samfundets strukturelle differentieringsgrad sietter som et bide funktionett og normativt imperativ. "Det societale fiellesskab" er et analytisk begreb, hormed vi fremhaver de krafter. der kendetegner det normative kompleks af samfundets integrale kerne. Det "societale" er således ikke et erstatningsbegreb for "det samfundsmassige". fordi vi med det societale ikke sâ meget peger pă effekterne af samfundet $\mathrm{i}$ sin totalitet. men derimod på de integrale kriefter, der muliggor dets eksistens som et system.

2. For et tentativt forsog pă at indkredse nogle af mikrostatens grundlaggende elementer, se Kaalhauge Nielsen (1999a). Denne artikel er en videreudivikling af en tale, jeg gav som officiel opponent ved den internationale konference "Microstates 99", 26-29 april, 1999 i det Nordiske Hus i Thorshavn. Faroerne.

3. Man kan skelne de "civilisatoriske aspekter" fra de kulturelle. De kulturelle aspekter er fienomener af en hojere analytisk orden, og deres effekt på historien er vasentligt forskellig fra den civilisatoriske dimension.

4. I den Faroske Hvidbogs diskussion af mikrostater fremgår det blandt andet, at fra 1975-1986 "blev eksporten diversificeret i 21 mikrostater, $\mathrm{og}$ i flere af dem endda vaesentligt. ... I den samme periode havde $26 \mathrm{mi}$ krostater făet en meget bredere markedssammensatning" (side 68). Se kapitel 5: "Smà stater med suveranitet" i Sigvaldson (1999).

5. Jeg definerer okonomisme som den type kognitiv adfaerd, som i studiet af de samfundsmassige fanomener tenderer mod at reducere ordningsformen af sociale strukturer til afledte effekter af de basale krefter, der opfattes som gyldige for det okonomiske felt.

6. Det er dog betydeligt svarere at opna societal baredygtighed. end det er at opna okonomisk baredygtighed. Det er ogsa derfor. et oliebonanza i Gronland ikke i dybeste forstand vil indeholde et svar pà sporgsmálet om baredygtighed. Det vil kun kunne give en losning pà sporgsmalet om okonomisk baredygtighed. men vil ikke indeholde nogen losning. had angar kriterierne for societal baeredygtighed.

\section{Litteratur}

Danielsen. Mogens. Thomas Andersen, Olafur Nielsen og Thorkild Knudsen (1998). Mal og strategier i den gronlandske erhernsudikling. Sulisa.

Det ridgivende udvalg vedrorende Cironlands okonomi (1998). Beretning om den okonomiske udvikling $i$ Gronland $i$ 1997/98, Kobenhavn: Statsministeriet.

Gronlands Statistik (1998). Statistisk Arbog Gronland I99s,

Kaalhauge Nielsen, Jens (1999a). Parameters for the Theoretical Analisis of Microstates. Arbejdspapir.

Kaalhauge Nielsen, Jens (1999b). The Microstate with a Hinterland or Greenland special Problems as a Microstate. Paper prasenteret pa den internationale konference "The Governance of Small Jurisdictions". 11-13 november. Malta.

Kaalhauge Nielsen, Jens $(1999 \mathrm{c})$. "A Coping Strategy for Greenland - An Analysis of Greenland 's Economic Dilemmas and an Investigation of the OECD report" $i$ Nils Aarsether og Jorgen Ole Bierenholdt (red.). The Reflexive North. MOST-CCPP (under udgivelse).

Mises, Ludwig von (1966/1949). /luman Action: A Treatise on Economics, Chicago: Henry Regnery Company.

Münch, Richard (1990). "Differentiation. Rationalization, Interpenetration: The Emergence of Modern Society". pp. 441-464 i Jeffrey C. Alexander og Paul Colomy (ed.), Differentiation Theory and Social Change. New York: Columbia Press.

Paldam. Martin (1994). Gronlands okonomiske whikling. Arhus: Aarhus Universitetsforlag.

Sigvaldson, Herluf (1999). Firoerne Hidhogen. September.

Thomasen. Henrik. et al. (1999). (ironlands otirnomi: In strutegi for fremtiden. Paris: OECD Documents. 